\title{
Factors that influence disease-specific quality of life or health status in patients with COPD: a systematic review and meta-analysis of Pearson correlations
}

\section{*Ioanna Tsiligiannia,b,c, Janwillem Kocksa, Nikolaos Tzanakis, Nikolaos Siafakas ${ }^{b}$, Thys van der Molen ${ }^{a}$}

\author{
a University Medical Center, University of Groningen, Groningen, The Netherlands \\ ${ }^{b}$ Department of Thoracic Medicine, Medical School, University of Crete, Crete, Greece. \\ Agia Barbara Health Care Centre, Heraklion, Crete, Greece.
}

Originally submitted 17th March 2010; revised version received 10th December 2010; accepted 15th January 2011; online 6th April 2011

\begin{abstract}
Background: A major goal in the management of chronic obstructive pulmonary disease (COPD) is to ensure that the burden of the disease for patients with COPD is limited and that patients will have the best possible quality of life.

Aims: To explore all the possible factors that could influence disease-specific quality of life and health status in patients with COPD.

Methods: A systematic review of the literature and a meta-analysis were performed to explore the factors that could have a positive or negative effect on quality of life and/or health status in patients with COPD.

Results: Quality of life and health status are determined by certain factors included gender, disease severity indices, lung function parameters, body mass index, smoking, symptoms, co-morbidity, depression, anxiety, and exacerbations. Factors such as dyspnoea, depression, anxiety and exercise tolerance were found to be more correlated with health status than the widely used spirometric values. Forced expiratory volume in one second had a weak to modest Pearson weighted correlation coefficient which ranged from -0.110 to -0.510 depending on the questionnaire used.

Conclusions: The broad range of determining factors suggests that, in order to reach the management goals, health status should be measured in addition to lung function in patients with COPD.

(C) 2011 Primary Care Respiratory Society UK. All rights reserved.

I Tsiligianni, et al. Prim Care Respir J 2011; 20(3): 257-268

http://dx.doi.org/10.4104/pcrj.2011.00029
\end{abstract}

Keywords chronic obstructive pulmonary disease, health status, quality of life, factor correlations, questionnaire, systematic review

See linked editorial by Jones on pg 227

The full version of this paper, with online Appendix,

is available at www.thepcrj.org

\section{Introduction}

Chronic obstructive pulmonary disease (COPD) is a prevalent disease in the general population and a considerable burden for patients with the disease. This burden differs between patient groups. Some patients can live their lives almost untouched by the disease, while others are almost completely handicapped. The burden of the disease does not follow the classic Global Initiative for Chronic Obstructive Lung Disease (GOLD) severity grades based on spirometry, as postulated by the current guidelines. 'It is widely accepted that the burden of the disease is determined by more than pulmonary function measured by the Tiffeneau index and forced expiratory volume in one second $\left(F E V_{1}\right)$. One way to indicate the burden of the disease to patients is assessment of health-related quality of life (HRQoL) and health status. Quality of life (QoL) in general refers to the patient's ability to enjoy normal life activities (Webster's New World

\footnotetext{
* Corresponding author: Dr loanna G Tsiligianni, University of Groningen, University Medical Center, Antonius Deusinglaan 1, Groningen, $9700 \mathrm{AD}$ The Netherlands. Tel: +31503637478 E-mail: pdkapa@yahoo.gr
} 
Medical Dictionary). HRQoL is more specific and is related to the part of the QoL that is determined by health. It may include dimensions such as general health status, mental, psychological and sleep status, ability to proceed with daily life, and social activities. Disease-specific QoL is that related to a certain disease. COPD-related QoL is considered to be the potential impact of COPD on HRQoL. Health status represents an overall evaluation of the state of the health of a person. When related to a specific disease, it is almost interchangeable with disease-specific QoL.

Health status measurement is becoming an important issue for the day-to-day management of COPD patients in both primary and secondary health care. ${ }^{2-9}$ Studies report that a shorter survival is related to worse health status/HRQoL. ${ }^{10-12}$ Since health status is considered a major goal in managing the disease, $^{13}$ physicians should be focused on improving it. The implementation of short instruments to measure health status has significantly improved their usage in daily clinical practice. ${ }^{14-24}$ However, the currently available health status questionnaires have a number of differences in the concepts included, and various items are unique in some questionnaires. ${ }^{25,26}$

The theoretical model of factors that potentially have an influence on health status includes factors such as age, gender, disease severity, lung function, body mass index (BMI), smoking status, symptoms, exercise capacity, co-morbidity, depression, anxiety, and exacerbations. ${ }^{27-38}$

The aim of the present review and meta-analysis is to present and discuss the published data of factors that could possibly play a role in COPD-related QoL or health status. The existing literature provides information on various factors that could be positively or negatively associated with COPD-related QoL although, to date, no literature exists that aggregates this knowledge in one report.

\section{Methods}

A systematic literature search was performed from 1984 to September 2009 in Pubmed, Embase and the Cochrane Collaboration for the keywords COPD, health status or quality of life, in conjunction with questionnaires, age, gender, BMI, smoking, COPD severity, FEV1, symptoms, exercise capacity, comorbidity, depression, anxiety, and exacerbations. Further articles were identified from the reference lists of the included articles.

In our review we included studies that used general health status questionnaires such as the Short Form Health Survey Questionnaire (SF-12) and SF-36, the Quality of Well Being scale (QWB), the Sickness Impact Profile scale (SIP), the Nottingham Health Profile scale (NHP), the European Quality of Life questionnaire (EuroQOL) and studies that used specific health status and QoL questionnaires such as the Chronic Respiratory Questionnaire (CRQ), the St George's Respiratory Questionnaire (SGRQ), the COPD Control Questionnaire (CCQ), the Quality of Life in Respiratory IIIness Questionnaire (QoL-RIQ), and the
Airways Questionnaire 20 (AQ-20) for the assessment of COPD.

The number of potentially relevant studies identified and screened for retrieval was 2391 for COPD and factors relating to quality of life and 1497 for COPD and factors relating to health status. A total of 3717 studies were excluded because the title or abstract showed that they were not relevant or because of duplications in keyword searching. Those most frequently excluded were interventional studies that were not within the goals of this review. Studies that reported comparisons of QoL questionnaires but did not report information on factors relating to quality of life or health status were also excluded. A total of 171 studies were retrieved for evaluation and are included in this review; 66 studies reported Pearson or Spearman correlation coefficients and are included in the meta-analysis.

\section{Statistical analysis}

A meta-analysis was conducted only of the 66 studies for which Pearson or Spearman correlations were available. In some questionnaires a high score indicates a good health status while in others a high score indicates a bad health status. To enable a comparison to be made between the correlation coefficients of the different questionnaires, the correlation coefficients were multiplied by -1 when the direction of the scoring was from bad (low score) to good (high score) (figures 1 and 2). The following questionnaire scores were transformed: Chinese 35-Item Quality of Life Instrument, CRQ, EuroQoL, EuroQol-Five-Dimension visual analogue scale (EQ-5D VAS), Mental Component Summary (MCS-12) and Physical Component Summary (PCS-12) of SF-12, Multidimensional Index of Quality of Life (MIQL), Perceived Quality of Life Scale (PQoL), QoL-RIQ, Quality of Life Scale (QoLS), QWB, and the Visual Simplified Respiratory Questionnaire (VSRQ). As a result, a high score on a questionnaire indicates much impairment/worse health status.

Pooled estimates of the correlation coefficients were calculated by transforming the correlation coefficients to Fisher's $z$ values. The resulting values were weighted with the inverse of the variance of the correlation coefficients. The $95 \%$ confidence intervals of the pooled weighted Fisher's $z$ values were also calculated, after which all the values were back-transformed to the metric of the correlation coefficients. ${ }^{39}$

\section{Results: factors that influence COPD HRQoL and health status}

The factors presented here have been mentioned in the literature in relation to QoL and health status in patients with COPD. Pearson weighted correlations and confidence intervals between various factors and questionnaires are reported in Table 1. In order to make Table 1 readable, we only show the relations between questionnaires and factors when at least three studies reported on these outcomes. All Pearson weighted correlations are shown in the Appendix (available online at www.thepcrj.org). Figure 1 shows Pearson weighted 


\begin{tabular}{|c|c|c|c|c|c|}
\hline Questionnaire (no of studies) & Factor & $\begin{array}{l}\text { Weighted } \\
\text { Pearson }\end{array}$ & $\begin{array}{l}\text { Weighted } \\
\text { Pearson } \\
\text { upper } 95\end{array}$ & $\begin{array}{l}\text { Weighted } \\
\text { Pearson } \\
\text { lower } 95\end{array}$ & $\begin{array}{l}\text { Total number } \\
\text { of patients } \\
\text { in studies (lower } \\
\text { and upper numbers) }\end{array}$ \\
\hline $\begin{array}{l}\text { SGRQ total }(n=29)^{17,32,35,42,49,50,61,62,67,70,76,80,82} \\
.84,87,96,98,104,109,111,113,117-119,121,124,126,127,129\end{array}$ & $\mathrm{FEV}_{1}$ & -0.285 & -0.156 & -0.404 & $5288(30-751)$ \\
\hline CCQ total $(n=3)^{19,75,79}$ & $\mathrm{FEV}_{1}$ & -0.405 & -0.285 & -0.513 & $562(58-329)$ \\
\hline$C R Q *(n=4)^{105,114,116,129}$ & $\mathrm{FEV}_{1}$ & -0.294 & -0.023 & -0.525 & $206(44-62)$ \\
\hline SGRQ total $(n=5)^{72,98-100,104}$ & BODE & 0.441 & 0.572 & 0.289 & $583(64-253)$ \\
\hline $\begin{array}{l}\text { SGRQ total }(n=19)^{17,35,42,49,53,58,61,67,70,76,87,96} \\
104,109,111,113,117,121,124\end{array}$ & Dyspnoea & 0.507 & 0.622 & 0.371 & $2510(30-560)$ \\
\hline $\begin{array}{l}\text { SGRQ total }(n=15)^{35,50,58,61,70,76,84,104,109,111} \\
113,117,121,127,144\end{array}$ & 6MWD & -0.342 & -0.221 & -0.453 & $2454(30-1217)$ \\
\hline SGRQ total $(n=5)^{17,50,56,96,150}$ & HADS anxiety & 0.462 & 0.610 & 0.283 & $574(41-218)$ \\
\hline SGRQ total $(n=5)^{17,50,56,96,150}$ & HADS depression & 0.528 & 0.662 & 0.321 & $574(41-218)$ \\
\hline \multicolumn{6}{|c|}{$\begin{array}{l}\text { The numbers in parentheses are the total number of studies assessed. } \\
\text { *The score was transformed so that a high score on a questionnaire indicates much impairment/worse health status. } \\
\text { BODE=body mass index (B), degree of airway obstruction (O), level of functional dyspnoea (D), and exercise capacity (E); CCQ=COPD Control Questionnaire; } \\
\text { CRQ=Chronic Respiratory Questionnaire; FEV }{ }_{1}=\text { forced expiratory volume in } 1 \text { second; HADS=Hospital Anxiety and Depression Scale; } 6 M W D=6 \text {-minute walk distance; } \\
\text { SGRQ=St George's Respiratory Questionnaire. }\end{array}$} \\
\hline
\end{tabular}

correlations between $\mathrm{FEV}_{1}$ and various QoL or health status questionnaires. Figure 2 shows the highest Pearson weighted correlations between different factors and questionnaires. Some factors such as gender and COPD severity are not included in Figures 1 and 2 or the Appendix because the studies did not provide correlations but only comparisons between groups $(p<0.05)$. Studies that used the SF-36 questionnaire were not included in Figures 1 and 2 or the Appendix because of the large number of different domains. However, their impact on health status is reported in the text.

\section{Demographic and anthropometric factors}

\section{a) Age}

The results relating to age are controversial. Higher age was reported as a negative predicting factor for the health status of patients with COPD in 17 studies. $7,20,28,29-32,38,40-48$ In eight studies we found no significant correlation between age and health status ${ }^{49.56}$ and, in another eight studies, it was reported that younger patients had worse health status. ${ }^{33,57-63}$ The meta-analysis includes only a small number of studies that reported correlations since the large majority of studies only reported comparisons between age groups. In the meta-analysis, age was found to be weakly associated with impairment of health status (Table 1, Figure 2).

\section{b) Gender}

In 18 studies female patients with COPD reported worse health status than male patients, ${ }^{7,29,30,33,3,35,37,38,41,43,48,51,64-70}$ both on total scores and on physical condition scores as assessed by the SF36. ${ }^{29,35}$ Ten studies reported no gender differences in health status. ${ }^{40,50,52-55,71-74}$ Only one study reported the opposite - that is, worse health status in men. ${ }^{28}$

\section{c) Body weight and body mass index}

Body weight and BMl are related to health status, with underweight patients having worse health status than patients of normal weight. $28,43,53,75-79$ Four studies reported that health status tends to be worse also in overweight patients. $.3,63,75,80$ Some studies reported no correlation between health status and BMI. ${ }^{31,49,58}$ The Pearson weighted correlation ranged from weak to modest, depending also on the questionnaire used. The strongest correlations were reported with the SGRQ and CCQ (Figure 2). Low lean body mass abnormalities and a low fat free mass index have also been associated with activity impairment and worse health status. ${ }^{53,81}$ In one study, worse health status was associated with a smaller proportion of type I fibres in peripheral muscles. ${ }^{80}$

\section{Lifestyle parameters \\ a) Smoking status}

Current smoking and a higher number of pack-years have a weak negative influence on health status. ${ }^{7,28,31,46,55,61,79,82-87}$ Some studies reported no correlation ${ }^{40,43,51,53}$ and one study found that smokers had a better health status. ${ }^{29}$ Second-hand smoke was also reported to be associated with poorer health status in patients with COPD..$^{88}$ 


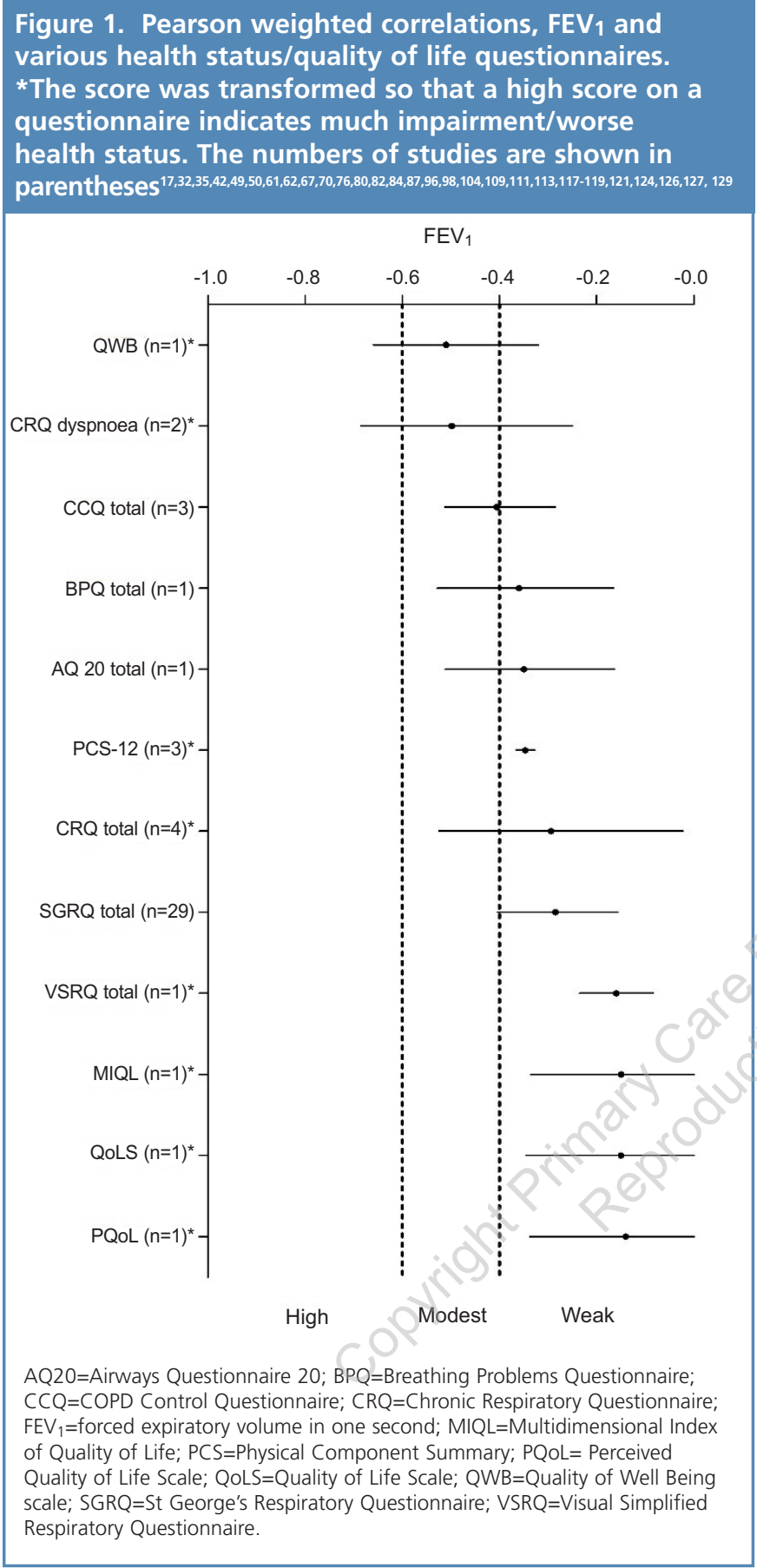

\section{b) Social class}

Some studies reported a relation between socioeconomic status and health status, ${ }^{83,89}$ but others did not confirm this finding. ${ }^{40,52}$

\section{Disease-driven determinants}

\section{a) Severity of COPD (GOLD-ATS-BTS-Canadian staging, BODE index)}

Most of the published studies suggest that COPD severity measured by recommendations from the ATS, BTS, GOLD, and the severity score is related to health status. ${ }^{8,29-31,38,40,43,46,67,75,90-102}$

With minor exceptions, health status became more significantly associated with disease severity as the disease passed to a more severe stage..$^{8,29-31,38,40,43,46,67,75,90-102}$ Yeo et al. ${ }^{103}$ reported no significant association between health status and GOLD stages. COPD severity assessed by the composite BODE index - body mass index (B), degree of airway obstruction $(O)$, level of functional dyspnoea (D), and exercise capacity (E) showed a better correlation with health status. This relation was stronger than the relation with pulmonary function parameters and GOLD stages (Table 1, Figure 2). ${ }^{72,98-100,104}$ A new composite index, the DOSE index - dyspnoea (D), airflow obstruction (O), smoking status (S), and exacerbation frequency (E) - showed a modest correlation with QoL in COPD patients. ${ }^{79}$

\section{b) Physiology (lung function values, $\mathrm{PaO}_{2}, \mathrm{PCO}_{2}$, exercise capacity)}

Most studies showed a non-significant or weak association between FEV 1 and health status. $28,30-31,33,35,42,43,45,47-49,53,56-59,61$. $64,67,68,70,76,82,84,87,89,98,104-127$ Some of the studies revealed a moderate association between health status and FEV 1 . $719,32,50,60,75,80,123,128-132$ The differences in the strength of the correlation might be due to the different questionnaires used (Table 1, Figure 1). The strongest correlations were shown mainly with the QWB, CRQ dyspnoea and CCQ questionnaire while, in all other questionnaires, the correlations were rather weak.

Other lung function values investigated included the inspiratory to total lung capacity (IC/TLC) ratio, ${ }^{35}$ forced expiratory volume in one second/forced vital capacity (FEV 1/FVC) ratio, , $31,42,80,105$ FVC, ${ }^{33,42,61,64,107}$ vital capacity $(\mathrm{VC}),{ }^{31,50,61,112,133} \mathrm{IC},{ }^{67,114}$ and residual volume (RV)/TLC ratio, ${ }^{63}$ most of which showed a weak association with health status. Maximal inspiratory respiratory muscle pressure (MIP), ${ }^{31,58,64}$ maximal expiratory respiratory muscle pressure (MEP), ${ }^{64}$ and carbon monoxide diffusing capacity were also found to be weakly associated with health status. . $^{31,50,63,64,96,105}$ Arterial oxygen tension $\left(\mathrm{PaO}_{2}\right)$ was either not significantly associated or modestly positively associated. $35,49,50,56,80,8,1,83,89,104,108,109,117,128,129,134 \mathrm{~A}$ weak negative association or a non-significant association was also reported with carbon dioxide tension $\left(\mathrm{PCO}_{2}\right)^{32,35,47,50,56,109}$

\section{Symptoms and exercise performance}

The key symptom in COPD is dyspnoea. Dyspnoea, which is usually measured with the transitional dyspnoea index (TDI) or the baseline dyspnoea index (BDI), was found to be strongly negatively associated with health status and had the highest correlations with health status questionnaires (Table 1, Figure 2). ${ }^{20,28-30,35,42,45,48 \text { - }}$ $53,57,58,60,61,63,65,67,70,75,76,79,81,87,93,94,96,97,101,104-114,117,123,124,131,133,135-141 \quad$ Sputum production, chronic cough, 29,102 wheezing, , $^{5,57}$ and fatigue ${ }^{58,110,139,142}$ were also negatively associated with health status.

Impairment of exercise performance tolerance was associated with impairment in health status and mainly with the functional status or activity domains. The most used instrument to assess the exercise tolerance was the 6-minute walk distance 


\section{Figure 2. Highest Pearson weighted correlations between various health status/quality of life questionnaires and factors that influence quality of life or health status. *The score was transformed so that a high score on a questionnaire indicates much impairment/worse health status. The numbers of studies are shown in parentheses $17,19,28,30,32-35,42,43,45,48-50,56,58,60-62,64,70,72,75,76,79,80,84,89,98-100,104,105,107,109,111,113,114,116-118,121,123,124,127-129,133,134,144,159$}

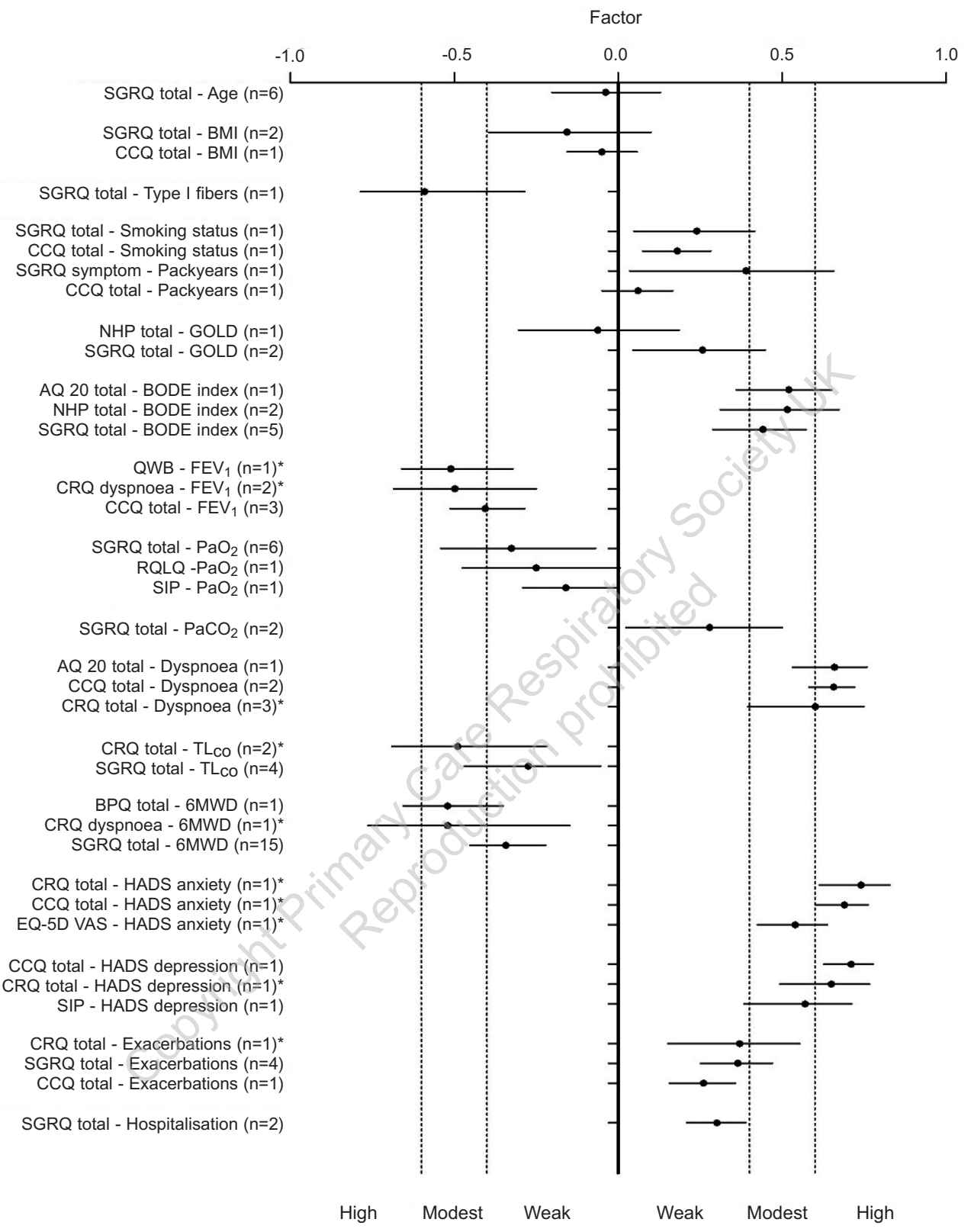

AQ20=Airways Questionnaire 20; BMI=body mass index; BODE index=body mass index (B), bronchial obstruction (O), dyspnoea (D), exercise (E); BPQ=Breathing Problems Questionnaire; $C C Q=C O P D$ Control Questionnaire; CRQ=Chronic Respiratory Questionnaire; EQ-5D-VAS=EuroQol-Five-Dimension Visual Analogue Scale; $\mathrm{FEV}_{1}=$ forced expiratory volume in one second; GOLD=Global Initiative for Chronic Obstructive Lung Disease; HADS=Hospital Anxiety and Depression Scale; $6 \mathrm{MWD}=6$-minute walk distance; $\mathrm{NHP}=$ Nottingham Health Profile scale; $\mathrm{PaCO}_{2}$, arterial carbon dioxide tension; $\mathrm{PaO}$, arterial oxygen tension; $\mathrm{QWB}=\mathrm{Quality}$ of Well Being scale; RQLQ=Modified Asthma Respiratory Quality of Life Questionnaire; SGRQ=St George's Respiratory Questionnaire; SIP=Sickness Impact Profile; TLCO, carbon monoxide diffusing capacity.

which was weakly to modestly correlated with health status measurement questionnaires (Table 1, Figure 2).35,50,52-54,58$61,64,70,73,76,81,83,84,87,104,105,109,111,113,114,116,117,121,127,133,138,143,144$ Only one study reported no association between health status and exercise capacity. ${ }^{145}$

\section{Co-morbidity: depression, anxiety}

Co-morbidity influences the health status of patients with COPD. ${ }^{28,35,38,41,48,51,62,91,92,103,115,146,147}$ Heart disease, hypertension, locomotive disorders, diabetes, and sleep disturbances are among the most common co-morbidities reported to be 


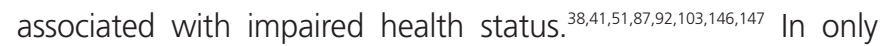
two studies was co-morbidity not associated with impaired health status..$^{53,99}$

Depression and anxiety strongly impair health status and QoL in patients with COPD, as reported in several studies. ${ }^{17,34,50,56,61-63,67,73,83,89,92,96,103,113,115,131,133,138,148-154}$ Depression and anxiety were assessed in most of the studies by the Hospital Anxiety and Depression Scale (HADS) and the Beck Depression Inventory Scale (BDI) and Anxiety Scale (BAI). The meta-analysis showed that depression and anxiety had among the highest correlations with various questionnaires for the assessment of health status (Table 1, Figure 2).

\section{Other factors}

Previous exacerbations and hospital admissions have a weak negative impact on health status. ${ }^{11,33,35,40,42,43,46,49,57,62,123,124,126,133,155-168}$ Lower education and non-compliance with medication and medical interventions are associated with a worse health status, $7,28,29,43,46,169$ as well as an increased number of medications for controlling COPD ${ }^{42,77,132,170}$ and a longer disease duration. ${ }^{42,46,120}$ Living alone was associated with poorer QoL. ${ }^{132}$

Seasonal variation in health status - with a better health status in spring/summer than in winter - has been reported..$^{157}$ In one study, a home temperature of at least $21^{\circ} \mathrm{C}$ for at least 9hrs/day was associated with better health status. ${ }^{171}$ There is also variability in health status between northern and southern countries and between urban and non-urban areas, with worse health status reported in southern countries and urban areas. ${ }^{28,42,172}$

Finally, psychological and psychosocial factors, and coping strategies are associated with health status. $33,48,52,120,173-175$ The patient's illness perception is also associated with several domains of QoL. ${ }^{175}$ One study found that the patient's coping strategies and health status were not significantly related. ${ }^{176}$ Holm et al. reported that a poor quality family relationship was associated with more psychological distress and dyspnoea resulting in a worse QoL. ${ }^{177}$ One study reported that employment status and, more specifically, COPD patients who were too disabled to work had worse QoL than paid workers. ${ }^{125}$

\section{Discussion}

Health status in patients with COPD is influenced by many different factors. However, the level of influence on health status of each factor is difficult to estimate because of the many different questionnaires used and because some factors influence different parts or domains of the available questionnaires. This metaanalysis shows that the most significant factors that determine QoL/health status in COPD patients are dyspnoea, depression, anxiety, and exercise tolerance. Since almost all instruments used to assess health status include items directly related to the disease - such as dyspnoea or other symptoms - this will automatically result in these strong associations. This meta-analysis also indicated that spirometry values are only weakly associated with health status. This finding supports the idea that health status should therefore be measured in addition to spirometry.

The results relating to age are controversial. Poorer health status was reported in both older and younger patients. Although the meta-analysis showed a trend for a worse health status in older COPD patients, the correlation was rather weak. The impairment of health status in older people is to be expected because ageing by itself leads to a deterioration in the health status of the general population and also impairs lung function. ${ }^{178}$ The presence of significant co-morbidities and/or an increased number of medications taken by older people leads to a further deterioration in health status. $7,59,67,77,92,103$ The fact that in some studies younger people reported worse health status may be explained by a larger gap between the health status experienced and that expected. ${ }^{59}$

Female patients with COPD report a poorer health status. ${ }^{7,29,30,33,35,37,38,41,43,48,51,64,70}$ Foy et al. investigated the effect of rehabilitation on health status in men and women and suggested that gender differences in physiological and psychological impairment explain the differences in health status. ${ }^{66}$ Other suggestions are an increased burden of symptoms, ${ }^{65}$ different coping mechanisms, ${ }^{37}$ more intense restriction of activity, ${ }^{33}$ an airway predominant phenotype, ${ }^{179}$ or a greater psychosocial impairment $^{69}$ in women. Women are also known to be more susceptible to depression, a disease that results in a deterioration in health status in COPD patients. ${ }^{66,180}$

Many studies assessed the effect of underweight on the health status in patients with COPD. Underweight patients have impaired health status mainly because of the deterioration in dyspnoea. ${ }^{53}$ This is well known in COPD patients. Overweight patients also have impaired health status. ${ }^{53,75}$ Shoup et al. reported that overweight patients with COPD had increased dyspnoea and worse scores on both the impact and total domains..53 Obesity leads to worse respiratory symptoms and less exercise capacity factors that are impaired in patients with COPD. ${ }^{181}$

Smoking and pack-years are considered important factors for health status.,31,106 Ex-smokers and smokers had significant differences in health status mainly because of the improvement in a range of respiratory symptoms after smoking cessation. 29,85,86 Ferrer et al. reported that, in smokers, mainly the impact and symptoms scores were impaired. ${ }^{7}$ Only Wijnhoven et al. reported that current smoking was associated with better QoL. ${ }^{29}$ The authors of that study suggested that this contradictory result could be due to confounding by severity. Patients in the study who continued to smoke were those with less severe disease. ${ }^{29}$ Although we expected that smoking would be among the best predictors of health status, the correlation was only weak but the number of studies was too small to make firm conclusions.

Most of the studies mentioned that disease severity was

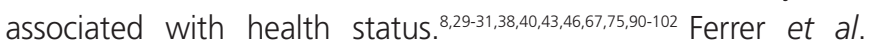


reported that HRQoL varied greatly within each stage of severity, even after stratification for co-morbidity. ${ }^{92}$ In the one study that reported no significant correlation between disease severity and health status, there was a trend towards higher scores in severe COPD which indicated a poorer quality of life. ${ }^{103}$ The BODE index was found to have a stronger correlation with health status than $\mathrm{FEV}_{1}$ (Table 1). This strong correlation is not surprising since the BODE index is composed of factors such as dyspnoea and exercise capacity that are domains of many health status questionnaires.

Although spirometry is traditionally seen as the most important determinator of the diagnosis and severity of COPD, this meta-analysis showed that the relation between health status and all spirometric values - mainly FEV 1 - is weak (Figure 1). This indicates that assessment of COPD severity in clinical practice could benefit from the additional measurement of health status.

Pearson weighted correlations from numerous studies revealed dyspnoea as a very important determinant of health status (Figure 2, Table 1, Appendix). The strong relation between dyspnoea and health status could in part be artificial because all reported questionnaires have questions or a domain about symptoms including dyspnoea. In a comparison of 11 instruments used for the assessment of health status in COPD, Stucki et al. reported that there was a large heterogeneity between questionnaires, but dyspnoea was the only factor present in all of them. ${ }^{26}$

Co-morbidity - especially depression and anxiety - has one of the greatest influences on the impairment of health status. . $^{34,50,56,61-63,67,73,83,89,92,96,103,115,131,133,138,148-154} \mathrm{An}$ increased number of chronic diseases is associated with a worse HRQoL in the general population. ${ }^{182}$ Few studies mentioned all the related co-morbidities in COPD patients with an impaired health status. $38,4,1,51,92,103,146,147$ Special attention has been given to depression and anxiety in a significant number of papers. Depression and anxiety have a significant impact on health status. All the questionnaires showed a good correlation with depression and anxiety questionnaires, but only the CCQ was reported to have a sufficiently good correlation to be used to predict depression and anxiety. ${ }^{34}$ Anxiety significantly influences the health status of patients with COPD and is strongly dependent on dyspnoea. ${ }^{61}$ The high correlation with depression and anxiety found in this meta-analysis highlights their important role in health status impairment and underlines the need for their estimation in daily clinical practice.

Surprisingly, both emotional and rational coping strategies impaired health status. ${ }^{52,173}$ Osman et al. reported that younger patients suffered more because of the psychological impact of their disease. ${ }^{33}$ Patients who deny their disease are less influenced by it. . $^{52}$ Those with positive beliefs and a less strong emotional reaction to the illness have better QoL. ${ }^{175}$

Since improvement in health status is a pivotal treatment goal, physicians should be informed about a patient's individual health status. Since only a very small part of health status is determined by spirometric values, the need for simultaneous assessment of health status by a proper instrument is crucial. However, it is difficult to select an instrument that is appropriate for use in clinical practice. Cazzola et al. (on behalf of the ATS/ERS task force on outcomes of COPD) suggested instruments for generic health status (SF-36, SIP, NHP), lung disease-specific health status and HRQoL (CRQ, SGRQ, QoL-RIQ), short disease-specific health status and HRQoL (CRQ-SAS, AQ-20, BPQ), disease-specific health status and HRQoL for patients with respiratory failure (Maugeri Foundation respiratory failure questionnaire) and the CCQ. ${ }^{25}$ Only a few of these instruments - such as the CCQ and AQ-20 - are applicable in daily clinical practice. In the future, the newly developed COPD Assessment Test (CAT) ${ }^{183}$ might be an alternative, although data comparing the psychometric properties with other questionnaires are too limited to include in this review.

\section{Conclusions}

Quality of life and health status are determined by a significant number of factors, the strongest of which are dyspnoea, depression, anxiety, and exercise tolerance. The results of this meta-analysis indicate that the health status of patients with COPD is only weakly associated with spirometric values. We consider it advisable to measure health status in addition to spirometry in order to be better informed about the influence of the disease on typical health status issues such as symptoms, impairment, and mental state.

\section{Acknowledgements}

The authors would like to thank Klaas Groenier of the Department of General Practice of the UMCG for his valuable help in conducting the meta-analysis.

\section{Conflicts of interest}

The authors declare that there are no conflicts of interest regarding this paper.

\section{Funding}

None.

\section{References}

1. Global Initiative for Chronic Obstructive Lung Disease. Updated December 2009. http://www.goldcopd.com.

2. Curtis JR, Deyo RA, Hudson LD. Pulmonary rehabilitation in chronic respiratory insufficiency. 7. Health related quality of life among patients with chronic obstructive pulmonary disease. Thorax 1994;49(2):162-70.

3. Jones PW. Issues concerning health-related quality of life in COPD. Chest 1995;107(5 Suppl):187-93S.

4. Jones PW. Health status and the spiral of decline. COPD 2009;6(1):59-63. http://dx.doi.org/10.1080/15412550802587943

5. Jones PW. Health status measurement in chronic obstructive pulmonary disease Thorax 2001;56(11):880-7. http://dx.doi.org/10.1136/thorax.56.11.880

6. Gigliotti F, Grazzini M, Stendardi L, Romagnoli I, Scano G. Quality of life and functional parameters in patients with chronic obstructive pulmonary disease (COPD): an update. Respir Med 2002;96(6):373-4. http://dx.doi.org/10.1053/rmed.2001.1275

7. Ferrer M, Villasante $\mathrm{C}$, Alonso J, et al. Interpretation of quality of life scores from the St George's Respiratory Questionnaire. Eur Respir J 2002;19(3):405-13. http://dx.doi.org/10.1183/09031936.02.00213202 
8. Punekar YS, Rodriguez-Roisin R, Sculpher M, Jones P, Spencer M. Implications of chronic obstructive pulmonary disease (COPD) on patients' health status: a western view. Respir Med 2007;101(3):661-9. http://dx.doi.org/10.1016/..rmed.2006.06.001

9. Arne $M$, Janson $C$, Janson $S$, et al. Physical activity and quality of life in subjects with chronic disease: chronic obstructive pulmonary disease compared with rheumatoid arthritis and diabetes mellitus. Scand I Prim Health Care 2009;27(3):141-7. http://dx.doi.org/10.1080/02813430902808643

10. Domingo-Salvany $A$, Lamarca $R$, et al. Health-related quality of life and mortality in male patients with chronic obstructive pulmonary disease. Am I Respir Crit Care Med 2002;166(5):680-5. http://dx.doi.org/10.1164/rccm.2112043

11. Fan VS, Curtis JR, Tu SP, McDonell MB, Finn SD; Ambulatory Care Quality Improvement Project Investigators. Using quality of life to predict hospitalization and mortality in patients with obstructive lung diseases. Chest 2002;122(2):429-36.

12. Antonelli-Incalzi R, Pedone $C$, Scarlata $S$, et al. Correlates of mortality in elderly COPD patients: focus on health-related quality of life. Respirology 2009;14(1):98104. http://dx.doi.org/10.1111/j.1440-1843.2008.01441.x

13. Santo Tomas LH, Varkey B. Improving health-related quality of life in chronic obstructive pulmonary disease. Curr Opin Pulm Med 2004;10(2):120-7.

14. Ware JE Jr, Gandek B. Overview of the SF-36 Health Survey and the International Quality of Life Assessment (IQoLA) Project. J Clin Epidemiol 1998;51(11):903-12.

15. Schunemann HJ, Goldstein R, Mador MJ, et al. A randomised trial to evaluate the self-administered standardised chronic respiratory questionnaire. Eur Respir J 2005;25(1):31-40. http://dx.doi.org/10.1183/09031936.04.00029704

16. Jacobs JE, Maille AR, Akkermans RP, van Weel C, Grol RP. Assessing the quality of life of adults with chronic respiratory diseases in routine primary care: construction and first validation of the 10-Item Respiratory IIIness Questionnaire-Monitoring 10 (RIQ-MON10). Qual Life Res 2004;13(6):1117-27. http://dx.doi.org/10.1023/ B:QURE.0000031338.88928.e9

17. Hajiro T, Nishimura K, Jones PW, et al. A novel, short, and simple questionnaire to measure health-related quality of life in patients with chronic obstructive pulmonary disease. Am J Respir Crit Care Med 1999;159(6):1874-78. http://dx.doi.org/10.1097/00008483-199911000-00016

18. Jones PW, Quirk FH, Baveystock CM. The St. George's Respiratory Questionnaire. Respir Med 1991;85(Suppl B):25-31.

19. Van der Molen T, Willemse BW, Schokker $\mathrm{S}$, ten Hacken NH, Postma DS, Juniper EF. Development, validity and responsiveness of the clinical COPD questionnaire. Health Qual Life Outcomes 2003;1(1):13.

20. Maille AR, Koning CJ, Zwinderman AH, Willems LN, Dijkman JH, Kaptein AA. The development of the 'Quality-of-life for Respiratory Illness Questionnaire (QOL$\mathrm{RIQ})^{\prime}$ : a disease specific quality of life questionnaire for patients with mild to moderate chronic non specific lung disease. Respir Med 1997;1(5):297-309. http://dx.doi.org/10.1016/S0954-6111(97)90034-2

21. Ware JJ, Sherbourne CD. The MOS 36-item short form health survey (SF-36): I. Conceptual framework and item selection. Med Care 1992;30(6):473-83.

22. Kind P. The EuroQoL instrument: an index of health-related quality of life. In: Spilker B, editor. Quality of Life and Pharmacoeconomics in Clinical Trials. 2. Philadelphia: Lippincott-Raven, 1996: 191-201.

23. Bergner M, Bobbit RA, Carter WB, Gilson BS. The Sickness Impact Profile: development and final revision of a health status measure. Med Care 1981;19(8):787-805. http://dx.doi.org/10.1097/00005650-198108000-00001

24. Williams JE, Singh SJ, Sewell L, Guyatt GH, Morgan MD. Development of a selfreported Chronic Respiratory Questionnaire (CRQ-SR). Thorax 2001;56(12):954-9. http://dx.doi.org/10.1136/thorax.56.12.954

25. Cazzola M, MacNee W, Martinez FJ, et al; American Thoracic Society; European Respiratory Society Task Force on outcomes of COPD. Outcomes for COPD pharmacological trials: from lung function to biomarkers. Eur Respir J 2008:31(2):416-69.

26. Stucki A, Stucki G, Cieza A, Schuurmans MM, Kostanjsek N, Ruof J. Content comparison of health-related quality of life instruments for COPD. Respir Med 2007;101(6):1113-22. http://dx.doi.org/10.1016/j.rmed.2006.11.016
27. Celli BR, Cote CG, Marin JM, et al. The body mass index, airflow obstruction, dyspnea, and exercise capacity index in chronic obstructive pulmonary disease. $N$ Engl J Med 2004;350(10):1005-12.

28. Hesselink $A E$, van der Windt DA, Penninx BW, et al. What predicts change in pulmonary function and quality of life in asthma or COPD? I Asthma 2006;43(7):513-19. http://dx.doi.org/10.1080/02770900600856954

29. Wijnhoven HA, Kriegsman DM, Hesselink AE, Penninx BW, de Haan $M$. Determinants of different dimensions of disease severity in asthma and COPD: pulmonary function and health-related quality of life. Chest 2001;119(4):1034-42. http://dx.doi.org/10.1378/chest.119.4.1034

30. Martin A, Rodriguez-Gonzalez Moro JM, Izquierdo JL, Gobartt E, de Lucas P; VICE Study Group. Health-related quality of life in outpatients with COPD in daily practice: the VICE Spanish Study. Int J Chron Obstruct Pulmon Dis 2008;3(4):683-92.

31. Tsukino M, Nishimura K, Ikeda A, Koyama H, Mishima M, Izumi T. Physiological factors that determine the health-related quality of life in patients with COPD. Chest 1996;110(4):896-903. http://dx.doi.org/10.1378/chest.110.4.896

32. Aibar Arregui MA, Laborda Ezquerra K, Conget Lopez F. Relationship between objective data and health-related quality of life in COPD patients. An Med Interna 2007;24(10):473-7.

33. Osman LM, Godden DJ, Friend JA, Legge JS, Douglas JG. Quality of life and hospital readmission in patients with chronic obstructive pulmonary disease. Thorax 1997;52(1):67-71

34. Cleland J, Lee A, Hall S. Associations of depression and anxiety with gender, age, health-related quality of life and symptoms in primary care COPD patients. Fam Pract 2007;24(3):217-23. http://dx.doi.org/10.1093/fampra/cmm009

35. De Torres J, Casanova C, Hernandez C, et al. Gender associated differences in determinants of quality of life in patients with COPD: a case series study. Health Qual Life Outcomes 2006;4:72.

36. Prescott E, Bjerg AM, Andersen PK, Lange P, Vestbo J. Gender differences in smoking effects on lung function and risk of hospitalisation for COPD: results from a Danish longitudinal population study. Eur Respir J 1997;10(4):822-7.

37. Leidy NK, Traver GA. Psychophysiologic factors contributing to functional performance in people with COPD: are there gender differences? Res Nurs Health 1995;18(6):535-46. http://dx.doi.org/10.1002/nur.4770180609

38. Antonelli-Incalzi R, Imperiale C, Bellia V, Catalano F, Scichilone N, Pistelli R, Rengo $\mathrm{F}$; SaRA Investigators. Do GOLD stages of COPD severity really correspond to differences in health status? Eur Respir J 2003;22(3):444-9. http://dx.doi.org/10.1183/09031936.03.00101203

39. Shadish WR, Haddock CK. Combining estimates of effect size. In: Cooper $H$, Hedges LV, editors. The Handbook of Research Synthesis. New York: Russell Sage Foundation, 1994: 265-6.

40. Ståhl E, Lindberg A, Jansson SA, et al. Health-related quality of life is related to COPD disease severity. Health Qual Life Outcomes 2005;3:56.

41. Van Manen JG, Bindels PJ, Dekker PJ, et al. The influence of COPD on healthrelated quality of life independent of the influence of comorbidity. J Clin Epidemiol 2003;56(12):1177-84.

42. Miravitlles M, Molina J, Naberan K, Cots JM, Ros F, Llor C; EVOCA study. Factors determining the quality of life of patients with COPD in primary care. Ther Adv Respir Dis 2007;1(2):85-92. http://dx.doi.org/10.1177/1753465807086097

43. Carrasco Garrido P, de Miguel Díez J, Rejas Gutiérrez J, et al. Negative impact of chronic obstructive pulmonary disease on the health-related quality of life of patients. Results of the EPIDEPOC study. Health Qual Life Outcomes 2006;4:31.

44. Peruzza S, Sergi G, Vianello A, et al. Chronic obstructive pulmonary disease (COPD) in elderly subjects: impact on functional status and quality of life. Respir Med 2003;97(6):612-17. http://dx.doi.org/10.1053/rmed.2003.1488

45. Rodríguez-González Moro JM, Izquierdo JL, Antón E, de Lucas P, Martín A; MUVICE Study Group. Health related quality of life in outpatient women with COPD in daily practice: the MUVICE Spanish study. Respir Med 2009;103(9):1303-12.

46. Izquierdo JL, Barcina $C$, Jiménez J, Muñoz M, Leal M. Study of the burden on patients with chronic obstructive pulmonary disease. Int J Clin Pract 2009;63(1):87- 
97. http://dx.doi.org/10.1111/j.1742-1241.2008.01936.x

47. Salik Y, Ozalevli S, Cimrin AH. Cognitive function and its effects on the quality of life status in the patients with chronic obstructive pulmonary disease (COPD). Arch Gerontol Geriatr 2007;45(3):273-80. http://dx.doi.org/10.1016/ j.archger.2006.12.002

48. Blinderman CD, Homel P, Billings JA, Tennstedt S, Portenoy RK. Symptom distress and quality of life in patients with advanced chronic obstructive pulmonary disease. J Pain Symptom Manage 2009;38(1):115-23. http://dx.doi.org/10.1016/j.jpainsymman.2008.07.006

49. de Miguel Díez J, Izquierdo Alonso JL, Rodríguez González-Moro JM, de Lucas Ramos P, Bellón Cano JM, Molina París J. Quality of life with chronic obstructive pulmonary disease: the influence of level of patient care. Arch Bronconeumol 2004;40(10):431-7.

50. Engstrom CP, Persson LO, Larsson S, Sullivan M. Health-related quality of life in COPD: why both disease-specific and generic measures should be used. Eur Respir J 2001;18(1):69-76. http://dx. doi.org/10.1183/09031936.01.00044901

51. van Manen JG, Bindels PJ, Dekker EW, et al. Added value of co-morbidity in predicting health-related quality of life in COPD patients. Respir Med 2001;95(6):496-504. http://dx. doi.org/10.1053/rmed.2001.1077

52. Ketelaars CA, Schlosser MA, Moster R, Huyer Abu-Saad H, Halfens RJ, Wouters EF. Determinants of health-related quality of life in patients with chronic obstructive pulmonary disease. Thorax 1996;51(1):39-43. http://dx.doi.org/10.1136/thx.51.1.39

53. Shoup R, Dalsky G, Warner S, et al. Body composition and health-related quality of life in patients with obstructive airways disease. Eur Respir J 1997;10(7):157680. http://dx.doi.org/10.1183/09031936.97.10071576

54. Jones PW, Baveystock CM, Littlejohns P. Relationships between general health measured with the sickness impact profile and respiratory symptoms, physiological measures, and mood in patients with chronic airflow limitation. Am Rev Respir Dis 1989;140(6):1538-43

55. Renwick DS, Connolly MJ. Impact of obstructive airways disease on quality of life in older adults. Thorax 1996;51(5):520-5. http://dx.doi.org/10.1136/thx.51.5.520

56. Okubadejo AA, Jones PW, Wedzicha JA. Quality of life in patients with chronic obstructive pulmonary disease and severe hypoxaemia. Thorax 1996;51(1):44-7.

57. Seemungal TA, Donaldson GC, Paul EA, Bestall JC, Jeffries DJ, Wedzicha JA. Effect of exacerbation on quality of life in patients with obstructive pulmonary disease. Am J Respir Crit Care Med 1998;157(5 Pt 1):1418-22.

58. Mangueira NM, Viega IL, Mangueira Mde A, Pinheiro AN, Costa Mdo R. Correlation between clinical parameters and health-related quality of life in women with COPD. J Bras Pneumol 2009;35(3):248-55.

59. Yohannes AM, Roomi J, Waters K, Connolly MJ. Quality of life in elderly patients with COPD: measurement and predictive factors. Respir Med 1998;92(10):1231-6. http://dx.doi.org/10.1016/S0954-6111(98)90426-7

60. Guyatt GH, Townsend M, Keller J, Singer J, Nogradi S. Measuring functional status in chronic lung disease: conclusions from a randomized control trial. Respir Med 1989;83(4):293-7

61. Martinez Frances ME, Perpina Tordera M, Belloch Fuster A, Martínez Moragón EM, Compte Torrero L. Impact of baseline and induced dyspnea on the quality of life of patients with COPD. Arch Bronconeumol 2008;44(3):127-34. http://dx.doi.org/10.1016/S1579-2129(08)60026-9

62. Hynninen MJ, Pallesen S, Nordhus $\mathbf{H}$. Factors affecting health status in COPD patients with co-morbid anxiety or depression. Int I Chron Obstruct Pulmon Dis 2007; 2(3):323-8

63. Moy ML, Reilly JJ, Ries AL, et al; National Emphysema Treatment Trial Research Group. Multivariate models of determinants of health-related quality of life in severe chronic obstructive pulmonary disease. J Rehabil Res Dev 2009;46(5):64354. http://dx.doi.org/10.1682/JRRD.2008.09.0127

64. Gonzalez E, Herrejon A, Inchaurraga I, Blanquer R. Determinants of health-related quality of life in patients with pulmonary emphysema. Respir Med 2005;99(5):63844. http://dx.doi.org/10.1016/..rmed.2004.09.019

65. Langhammer A, Johnsen R, Holmen J, Gulsvik A, Bjermer L. Cigarette smoking gives more respiratory symptoms among women than among men. The NordTrondelag Health Study (HUNT). J Epidemiol Community Health 2000;54(12):91722. http://dx.doi.org/10.1136/jech.54.12.917

66. Foy CG, Rejeski WJ, Berry MJ, Zaccaro D, Woodard CM. Gender moderates the effects of exercise therapy on health-related quality of life among COPD patients. Chest 2001;119(1):70-6. http://dx.doi.org/10.1378/chest.119.1.70

67. Di Marco F, Verga M, Reggente $M$, et al. Anxiety and depression in COPD patients: the role of gender and disease severity. Respir Med 2006;100(10):1767-74.

68. Rodrigue JR, Baz MA. Are there sex differences in health-related quality of life after lung transplantation for chronic obstructive pulmonary disease? I Heart Lung Transplant 2006;25(1):120-5. http://dx.doi.org/10.1016/..healun.2005.02.005

69. Low G, Gutman G. Examining the role of gender in health-related qualityof life: perceptions of older adults with chronic obstructive pulmonary disease. J Gerontol Nurs 2006;32(11):42-9.

70. Katsura H, Yamada K, Wakabayashi R, Kida K. Gender-associated differences in dyspnoea and health-related quality of life in patients with chronic obstructive pulmonary disease. Respirology 2007;12(3):427-32. http://dx.doi.org/ 10.1111/j.1440-1843.2007.01075.x

71. Skumlien S, Haave E, Morland L, Bjørtuft O, Ryg MS. Gender differences in the performance of activities of daily living among patients with chronic obstructive pulmonary disease. Chron Respir Dis 2006;3(3):141-8. http://dx.doi.org/ 10.1191/1479972306cd114oa

72. Medinas-Amorós M, Alorda C, Renom F, et al. Quality of life in patients with chronic obstructive pulmonary disease: the predictive validity of the BODE index. Chron Respir Dis 2008;5(1):7-11. http://dx.doi.org/10.1177/1479972307082329

73. Kühl K, Schürmann W, Rief W. Mental disorders and quality of life in COPD patients and their spouses. Int J Chron Obstruct Pulmon Dis 2008;3(4):727-36.

74. Camelier A, Rosa FW, Jones PW, Jardim JR. Brazilian version of airways questionnaire 20: a reproducibility study and correlations in patients with COPD. Respir Med 2005;99(5):602-08. http://dx.doi.org/10.1016/j.rmed.2004.09.022

75. Damato S, Bonatti C, Frigo V, et al. Validation of the clinical COPD questionnaire in Italian language. Health Qual Life Outcomes 2005;3:9.

76. Katsura H, Yamada K, Kida K. Both generic and disease specific health-related quality of life are deteriorated in patients with underweight COPD. Respir Med 2005;99(5):624-30. http://dx.doi.org/10.1016/j.rmed.2004.09.017

77. Miravitlles M, Alvarez-Sala JL, Lamarca R, et al; IMPAC Study Group. Treatment and quality of life in patients with chronic obstructive pulmonary disease. Qual Life Res 2002;11(4):329-38

78. Stojkovic J, Stevcevska G. Quality of life, forced expiratory volume in one second and body mass index in patients with COPD, during therapy for controlling the disease. Prilozi 2009;30(1):129-42.

79. Jones RC, Donaldson GC, Chavannes NH, et al. Derivation and validation of a composite index of severity in chronic obstructive pulmonary disease - the DOSE Index. Am J Respir Crit Care Med 2009;180(12):1189-95. http://dx.doi.org/10.1164/rccm.200902-02710C

80. Montes de Oca M, Torres SH, Gonzalez Y, et al. Peripheral muscle composition and health status in patients with COPD. Respir Med 2006;100(10):1800-06. http://dx.doi.org/10.1016/j.rmed.2006.01.020

81. Mostert R, Goris A, Weling-Scheepers C, Wouters EF, Schols AM. Tissue depletion and health related quality of life in patients with chronic obstructive pulmonary disease. Respir Med 2000;94(9):859-67. http://dx.doi.org/10.1053/rmed.2000.0829

82. Spencer S, Calverley PM, Sherwood Burge P, Jones PW; ISOLDE Study Group. Inhaled steroids in obstructive lung disease. Health status deterioration in patients with chronic obstructive pulmonary disease. Am J Respir Crit Care Med 2001; 163(1):122-8

83. Prigatano GP, Wright EC, Levin D. Quality of life and its predictors in patients with mild hypoxemia and chronic obstructive pulmonary disease. Arch Intern Med 1984;144(8):1613-19. http://dx.doi.org/10.1001/archinte.144.8.1613

84. Heijdra YF, Pinto-Plata VM, Kenney LA, Rassulo J, Celli BR. Cough and phlegm are important predictors of health status in smokers without COPD. Chest 
2002;121(5):1427-33. http://dx.doi.org/10.1378/chest.121.5.1427

85. Tillmann M, Silcock J. A comparison of smokers' and ex-smokers' health related quality of life. J Public Health Med 1997;19(3):268-73.

86. Wilson D, Parsons J, Wakefied M. The health-related quality-of-life of never smokers, ex smokers, and light, moderate, and heavy smokers. Prev Med 1999;29(3):139-44. http://dx.doi.org/10.1006/pmed.1999.0523

87. Nunes DM, Mota RM, de Pontes Neto OL, Pereira ED, de Bruin VM, de Bruin PF. Impaired sleep reduces quality of life in chronic obstructive pulmonary disease. Lung 2009;187(3):159-63. http://dx.doi.org/10.1007/s00408-009-9147-5

88. Eisner MD, Iribarren C, Yelin EH, Sidney S, Katz PP, Sanchez G, Blanc PD. The impact of SHS exposure on health status and exacerbations among patients with COPD. Int J Chron Obstruct Pulmon Dis 2009;4(1):169-76.

89. McSweeny AJ, Grant I, Heaton RK, Adams KM, Timms RM. Life quality of patients with chronic obstructive pulmonary disease. Arch Intern Med 1982;142(3):473-8. http://dx.doi.org/10.1001/archinte.142.3.473

90. Eisner MD, Trupin L, Katz PP, et al. Development and validation of a survey-based COPD severity score. Chest 2005;127(6):1890-7. http://dx.doi.org/ 10.1378/chest.127.6.1890

91. Rutten-van Molken MP, Oostenbrink JB, Burkhart DP, Burkhart D, Monz BU. Does quality of life of COPD patients as measured by the generic EuroQol five-dimension questionnaire differentiate between COPD severity stages? Chest 2006;130(4):1117-28. http://dx.doi.org/10.1378/chest.130.4.1117

92. Ferrer $\mathrm{M}$, Alonso J, Morera J, et al. Chronic obstructive pulmonary disease stage and health-related quality of life. Ann Intern Med 1997;127(12):1072-9.

93. Hajiro T, Nishimura K, Tsukino M, Ikeda A, Oga T, Izumi T. A comparison of the level of dyspnea vs disease severity in indicating the health-related quality of life of patients with COPD. Chest 1999;116(6):1632-7. http://dx.doi.org/ 10.1378/chest.116.6.1632

94. Mahler DA, Mackowiak J. Evaluation of the Short-Form 36 Questionnaire to measure health-related quality of life in patients with COPD. Chest 1995;107(6):1585-9.

95. Miravitlles M, Llor C, de Castellar R, Izquierdo I, Baró E, Donado E. Validation of the COPD severity score for use in primary care: the NEREA study. Eur Respir J 2009;33(3):519-27. http://dx.doi.org/10.1183/09031936.00087208

96. Hajiro T, Nishimura K, Tsukino M, Ikeda A, Oga T. Stages of disease severity and factors that affect the health status of patients with chronic obstructive pulmonary disease. Respir Med 2000;94(9):841-6. http://dx.doi.org/10.1053/rmed.2000.0804

97. Voll-Aanerud M, Eagan TM, Wentzel-Larsen T, Gulsvik A, Bakke PS. Respiratory symptoms, COPD severity, and health related quality of life in a general population sample. Respir Med 2008;102(3):399-406.

98. Huijsmans RJ, de Haan A, ten Hacken NN, Straver RV, van't Hul AJ.The clinical utility of the GOLD classification of COPD disease severity in pulmonary rehabilitation. Respir Med 2008;102(1):162-71. http://dx.doi.org/10.1016/j.rmed.2007.07.008

99. Medinas Amorós M, Mas-Tous C, Renom-Sotorra F, Rubí-Ponseti M, CentenoFlores MJ, Gorriz-Dolz MT.Health-related quality of life is associated with COPD severity: a comparison between the GOLD staging and the BODE index. Chron Respir Dis 2009;6(2):75-80. http://dx.doi.org/10.1177/1479972308101551

100. Ong KC, Lu SJ, Soh CS. Does the multidimensional grading system (BODE) correspond to differences in health status of patients with COPD? Int J Chron Obstruct Pulmon Dis 2006;1(1):91-6. http://dx.doi.org/10.2147/copd.2006.1.1.91

101. Schlecht NF, Schwartzman K, Bourdeau J. Dyspnea as clinical indicator in patients with chronic obstructive pulmonary disease. Chron Respir Dis 2005;2(4):183-91. http://dx.doi.org/10.1191/1479972305cd079oa

102. Maleki-Yazdi MR, Lewczuk CK, Haddon JM, Choudry N, Ryan N. Early detection and impaired quality of life in COPD GOLD stage 0: a pilot study. COPD 2007;4(4):313-20. http://dx.doi.org/10.1080/15412550701595740

103. Yeo J, Karimova G, Bansal S. Co-morbidity in older patients with COPD- its impact on health service utilisation and quality of life, a community study. Age Ageing 2006;35(1):33-7. http://dx.doi.org/10.1093/ageing/afj002

104. Sanchez FF, Faganello MM, Tanni SE, Lucheta PA, Padovani CR, Godoy I.
Relationship between disease severity and quality of life in patients with chronic obstructive pulmonary disease. Braz J Med Biol Res 2008;41(10):860-5. http://dx.doi.org/10.1590/S0100-879X2008005000043

105. Sans-Torres J, Domingo C, Rue M, Durán-Tauleria E, Marín A. An assessment of the quality of life of patients with COPD and chronic hypoxemia by using the Spanish version of the Chronic Respiratory Disease Questionnaire. Arch Bronconeumol 1999;35(9):428-34.

106. Schrier AC, Dekker FW, Kaptein AA, Dijkman JH. Quality of life in elderly patients with chronic nonspecific lung disease seen in family practice. Chest 1990;98(4):894-9. http://dx.doi.org/10.1378/chest.98.4.894

107. Xie G, Li Y, Shi P, Zhou B, Zhang P, Wu Y. Baseline pulmonary function and quality of life 9 years later in a middle-aged Chinese population. Chest 2005;128(4):244857. http://dx.doi.org/10.1378/chest.128.4.2448

108. Alonso J, Prieto L, Ferrer M, et al. Testing the measurement properties of the Spanish version of the SF-36 Health Survey among male patients with chronic obstructive pulmonary disease. Quality of Life in COPD Study Group. I Clin Epidemiol 1998;51(11):1087-94. http://dx.doi.org/10.1016/S0895-4356(98)00100-0

109. Katsura H, Yamada K, Wakabayashi R, Kida K. The impact of dyspnoea and leg fatigue during exercise on health-related quality of life in patients with COPD. Respirology 2005;10(4):485-90. http://dx.doi.org/10.1111/j.14401843.2005.00729.x

110. Boueri FM, Bucher-Bartelson BL, Glenn KA, Make BJ. Quality of life measured with a generic instrument (Short Form 36) improves following pulmonary rehabilitation in patients with COPD. Chest 2001;119(1):77-84. http://dx.doi.org/10.1378/chest.119.1.77

111. Barr JT, Schumacher GE, Freeman S, LeMoine M, Bakst AW, Jones PW. American translation, modification, and validation of the St. George's Respiratory Questionnaire. Clin Ther 2000;22(9):1121-45. http://dx.doi.org/10.1016/S01492918(00)80089-2

112. Mahler DA, Faryniarz K, Tomlinson D, et al. Impact of dyspnea and physiologic function on general health status in patients with chronic obstructive pulmonary disease. Chest 1992;102(2):395-401. http://dx.doi.org/10.1378/chest.102.2.395

113. Jones PW, Quirk FH, Baveystock CM, Littlejohns P. A self-complete measure of health status for chronic airflow limitation. The St. George's Respiratory Questionnaire. Am Rev Respir Dis 1992;145(6):1321-7.

114. Wegner RE, Jörres RA, Kirsten DK, Magnussen H. Factor analysis of exercise capacity, dyspnoea ratings and lung function in patients with severe COPD. Eur Respir J 1994;7(4):725-9. http://dx.doi.org/10.1183/09031936.94.07040725

115. Cully JA, Graham DP, Stanley MA, et al. Quality of life in patients with chronic obstructive pulmonary disease and comorbid anxiety or depression. Psychosomatics 2006;47(4):312-19. http://dx.doi.org/10.1176/appi.psy.47.4.312

116. Güell R, Casan P, Sangenís M, Morante F, Belda J, Guyatt GH. Quality of life in patients with chronic respiratory disease: the Spanish version of the Chronic Respiratory Questionnaire (CRQ). Eur Respir J 1998;11(1):55-60. http://dx.doi.org/10.1183/09031936.98.11010055

117. Sant'Anna CA, Stelmach R, Zanetti Feltrin MI, Filho WJ, Chiba T, Cukier A. Evaluation of health-related quality of life in low-income patients with COPD receiving long-term oxygen therapy. Chest 2003;123(1):136-41. http://dx.doi.org/10.1378/chest.123.1.136

118. Perez T, Arnould B, Grosbois JM, et al; on behalf of TIPHON Study Group. Validity, reliability, and responsiveness of a new short Visual Simplified Respiratory Questionnaire (VSRQ) for health-related quality of life assessment in chronic obstructive pulmonary disease. Int J Chron Obstruct Pulmon Dis 2009;4:9-18.

119. El Rhazi K, Nejjari C, Benjelloun MC, et al. Validation of the St. George's Respiratory Questionnaire in patients with COPD or asthma in Morocco. Int $J$ Tuberc Lung Dis 2006;10(11):1273-8.

120. Andenaes R, Kalfoss MH, Wahl A. Psychological distress and quality of life in hospitalized patients with chronic obstructive pulmonary disease. J Adv Nurs 2004;46(5):523-30. http://dx.doi.org/10.1111/j.1365-2648.2004.03026.x

121. Katsura H, Yamada K, Kida K. Usefulness of a linear analog scale questionnaire to 
measure health-related quality of life in elderly patients with chronic obstructive pulmonary disease. J Am Geriatr Soc 2003;51(8):1131-5. http://dx.doi.org/10.1046/j.1532-5415.2003.51363.x

122. Moreira GL, Pitta F, Ramos D, et al. Portuguese-language version of the Chronic Respiratory Questionnaire: a validity and reproducibility study. J Bras Pneumol 2009;35(8):737-44.

123. Aaron SD, Vandemheen KL, Clinch JJ, et al. Measurement of short-term changes in dyspnea and disease-specific quality of life following an acute COPD exacerbation. Chest 2002;121(3):688-96. http://dx.doi.org/10.1378/chest.121.3.688

124. Wang Q, Bourdeau J. Outcome and health-related quality of life following hospitalisation for an acute exacerbation of COPD. Respirology 2005;10(3):334-40.

125. Orbon KH, Schermer TR, van der Gulden JW, et al. Employment status and quality of life in patients with chronic obstructive pulmonary disease. Int Arch Occup Environ Health 2005;78(6):467-74. http://dx.doi.org/10.1007/s00420-005-0617-7

126. Spencer S, Calverley PM, Burge PS, Jones PW. Impact of preventing exacerbations on deterioration of health status in COPD. Eur Respir J 2004;23(5):698-702. http://dx.doi.org/10.1183/09031936.04.00121404

127. Haave E, Hyland ME, Skumlien S. The relation between measures of health status and quality of life in COPD. Chron Respir Dis 2006;3(4):195-9. http://dx.doi.org/10.1177/1479972306070069

128. Kaplan RM, Atkins CJ, Timms R. Validity of a quality of well-being scale as an outcome measure in chronic obstructive pulmonary disease. I Chronic Dis 1984;37(2):85-95.

129. Pereira ED, Pinto R, Alcantara M, Medeiros M, Mota RM. Influence of respiratory function parameters on the quality of life of COPD patients. I Bras Pneumol 2009;35(8):730-6.

130. Chen H, Eisner MD, Katz PP, Yelin EH, Blanc PD. Measuring disease-specific quality of life in obstructive airway disease: validation of a modified version of the airways questionnaire 20. Chest 2006;129(6):1644-52. http://dx.doi.org/10.1378/chest.129.6.1644

131. Bentsen SB, Henriksen AH, Wentzel-Larsen T, Hanestad BR, Wahl AK. What determines subjective health status in patients with chronic obstructive pulmonary disease: importance of symptoms in subjective health status of COPD patients. Health Qual Life Outcomes 2008;6:115. http://dx.doi.org/10.1186/1477-7525-6-115

132. Incalzi RA, Bellia V, Maggi S, et al; Sa.R.A. Study Group. Reversible bronchial obstruction and disease-related health status in COPD. Qual Life Res 2002;11(6):517-25.

133. Duiverman ML, Wempe JB, Bladder G, Kerstjens HA, Wijkstra PJ. Health-related quality of life in COPD patients with chronic respiratory failure. Eur Respir $J$ 2008;32(2):379-86. http://dx.doi.org/10.1183/09031936.00163607

134. Stavem K, Erikssen J, Boe J. Health-related quality of life is associated with arterial $\mathrm{P}(\mathrm{O} 2)$ in chronic obstructive pulmonary disease. Respir Med 2000;94(8):772-7.

135. Ries AL. Impact of chronic obstructive pulmonary disease on quality of life: the role of dyspnea. Am J Med 2006;119(10 Suppl 1):12-20. http://dx.doi.org/ 10.1016/j.amjmed.2006.08.003

136. Bestall JC, Paul EA, Garrod R, Garnham R, Jones PW, Wedzicha JA. Usefulness of the Medical Research Council (MRC) dyspnoea scale as a measure of disability in patients with chronic obdtructive pulmonary disease. Thorax 1999;54(7):581-6. http://dx.doi.org/10.1136/thx.54.7.581

137. Bridevaux PO, Gerbase MW, Probst-Hensch NM, Schindler C, Gaspoz JM, Rochat T. Long-term decline in lung function, utilisation of care and quality of life in modified GOLD stage 1 COPD. Thorax 2008;63(9):768-74. http://dx.doi.org/10.1136/thx.2007.093724

138. Hu J, Meek P. Health-related quality of life in individuals with chronic obstructive pulmonary disease. Heart Lung 2005;34(6):415-22. http://dx.doi.org/ 10.1016/j.hrtlng.2005.03.008

139. Reardon J, Lareau S, Zu Wallack R. Functional status and quality of life in chronic obstructive pulmonary disease. Am J Med 2006;119(10 Suppl 1):32-7. http://dx.doi.org/10.1016/j.amjmed.2006.08.005

140. Partridge MR, Miravitlles M, Ståhl E, Karlsson N, Svensson K, Welte T. Development and validation of the Capacity of Daily Living during the Morning and Global Chest

PRIMARY CARE RESPIRATORY JOURNAL

www.thepcrj.org
Symptoms Questionnaires in COPD. Eur Respir J 2010;36(1):96-104. http://dx.doi.org/10.1183/09031936.00123709

141. Karapolat H, Eyigor S, Atasever A, Zoghi M, Nalbantgil S, Durmaz B. Effect of dyspnea and clinical variables on the quality of life and functional capacity in patients with chronic obstructive pulmonary disease and congestive heart failure. Chin Med J 2008;121(7):592-6.

142. Breslin E, van der Schans C, Breuklink S, et al. Perception of fatigue and quality of life in patients with COPD. Chest 1998;114(4):958-64. http://dx.doi.org/10.1378/chest.114.4.958

143. Curtis JR, Patrick DL. The assessment of health status among patients with COPD. Eur Respir J Suppl 2003;41:36s-45s. http://dx.doi.org/10.1183/09031936.03.00078102

144. Brown CD, Benditt JO, Sciurba FC, et al; National Emphysema Treatment Trial Research Group. Exercise testing in severe emphysema: association with quality of life and lung function. COPD 2008;5(2):117-24. http://dx.doi.org/ 10.1080/15412550801941265

145. Wijkstra PJ, TenVergert EM, van der Mark TW, et al. Relation of lung function, maximal inspiratory pressure, dyspnoea, and quality of life with exercise capacity in patients with chronic obstructive pulmonary disease. Thorax 1994;49(5):468-72. http://dx.doi.org/10.1136/thx.49.5.468

146. Crisafulli E, Costi S, Luppi F, et al. Role of comorbidities in a cohort of patients with COPD undergoing pulmonary rehabilitation. Thorax 2008;63(6):487-92. http://dx.doi.org/10.1136/thx.2007.086371

147. Wijnhoven HA, Kriegsman DM, Hesselink AE, de Haan M, Schellevis FG. The influence of co-morbidity on health-related quality of life in asthma and COPD patients. Respir Med 2003;97(5):468-75. http://dx.doi.org/10.1053/rmed.2002.1463

148. Kim HF, Kunik ME, Molinari VA, et al. Functional impairment in COPD patients: the impact of anxiety and depression. Psychosomatics 2000;41(6):465-71. http://dx.doi.org/10.1176/appi.psy.41.6.465

149. Stage KB, Middelboe T, Stage TB, Sørensen CH. Depression in COPD management and quality of life considerations. Int J Chron Obstruct Pulmon Dis 2006;1(3):31520. http://dx.doi.org/10.2147/copd.2006.1.3.315

150. Bosley CM, Corden ZM, Rees PJ, Cochrane GM. Psychological factors associated with use of home nebulized therapy for COPD. Eur Respir J 1996;9(11):2346-50. http://dx.doi.org/10.1183/09031936.96.09112346

151. Omachi TA, Katz PP, Yelin EH, et al. Depression and health-related quality of life in chronic obstructive pulmonary disease. Am J Med 2009;122(8):778.e9-15.

152. Felker B, Katon W, Hedrick SC, et al. The association between depressive symptoms and health status in patients with chronic pulmonary disease. Gen Hosp Psychiatry 2001;23(2):56-61. http://dx.doi.org/10.1016/S0163-8343(01)00127-X

153. Gudmundsson G, Gislason T, Janson C, et al. Depression, anxiety and health status after hospitalisation for COPD. Respir Med 2006;100(1):87-93. http://dx.doi.org/10.1016/j.rmed.2005.04.003

154. Ng TP, Niti M, Tan WC, Cao Z, Ong KC, Eng P. Depressive symptoms and chronic obstructive pulmonary disease: effect on mortality, hospital readmission, symptom burden, functional status, and quality of life. Arch Intern Med 2007;167(1):60-7. http://dx.doi.org/10.1001/archinte.167.1.60

155. Doll H, Miravitlles M. Health-related QOL in acute exacerbations of chronic bronchitis and chronic obstructive pulmonary disease: a review of the literature. Pharmacoeconomics 2005;23(4):345-63.

156. Miravitlles M, Calle M, Alvarez-Gutierrez F, Gobartt E, López F, Martín A. Exacerbations, hospital admissions and impaired health status in chronic obstructive pulmonary disease. Qual Life Res 2006;15(3):471-80. http://dx.doi.org/10.1007/s11136-005-3215-y

157. Miravitlles M, Ferrer M, Pont A, et al; IMPAC Study Group. Effect of exacerbations on quality of life in patients with chronic obstructive pulmonary disease: a two year follow-up study. Thorax 2004;59(5):387-95.

158. Gudmundsson G, Gislason T, Janson C, et al. Risk factors for rehospitalisation in COPD: role of health status, anxiety and depression. Eur Respir J 2005;26(3):4149. http://dx.doi.org/10.1183/09031936.05.00078504

159. Bourbeau J, Ford G, Zackon H, Pinsky N, Lee J, Ruberto G. Impact on patients' health status following early identification of a COPD exacerbation. Eur Respir $J$ 
I Tsiligianni et al.

2007;30(5):907-13. http://dx.doi.org/10.1183/09031936.00166606

160. Nishimura K, Sato S, Tsukino M, et al. Effect of exacerbations on health status in subjects with chronic obstructive pulmonary disease. Health Qual Life Outcomes 2009;7:69. http://dx.doi.org/10.1186/1477-7525-7-69

161. Esteban C, Quintana JM, Moraza J, et al. Impact of hospitalisations for exacerbations of COPD on health-related quality of life. Respir Med 2009;103(8):1201-08. http://dx.doi.org/10.1016/j.rmed.2009.02.002

162. Lior C, Molina J, Naberan K, Cots JM, Ros F, Miravitlles M; EVOCA Study Group. Exacerbations worsen the quality of life of chronic obstructive pulmonary disease patients in primary healthcare. Int J Clin Pract 2008;62(4):585-92. http://dx.doi.org/10.1111/j.1742-1241.2008.01707.x

163. Xu W, Collet JP, Shapiro $S$, et al. Negative impacts of unreported COPD exacerbations on health-related quality of life at one year. Eur Respir J 2010;35(5):1022-30. http://dx.doi.org/10.1183/09031936.00079409

164. Anzueto A, Leimer I, Kesten S. Impact of frequency of COPD exacerbations on pulmonary function, health status and clinical outcomes. Int J Chron Obstruct Pulmon Dis 2009;4(2):245-51.

165. Langsetmo L, Platt RW, Ernst P, Bourbeau J. Underreporting exacerbation of chronic obstructive pulmonary disease in a longitudinal cohort. Am J Respir Crit Care Med 2008;177(4):396-401. http://dx.doi.org/10.1164/rccm.200708-12900C

166. Spencer S, Jones PW; GLOBE Study Group. Time course of recovery of health status following an infective exacerbation of chronic bronchitis. Thorax 2003;58(7):58993. http://dx.doi.org/10.1136/thorax.58.7.589

167. Balcells E, Antó JM, Gea J, et al; PAC-COPD Study Group. Characteristics of patients admitted for the first time for COPD exacerbation. Respir Med 2009;103(9):1293302. http://dx.doi.org/10.1016/j.rmed.2009.04.001

168. O'Reilly JF, Williams AE, Rice L. Health status impairment and costs associated with COPD exacerbation managed in hospital. Int J Clin Pract 2007;61(7):1112-20. http://dx.doi.org/10.1111/j.1742-1241.2007.01424.x

169. Corden ZM, Bosley CM, Rees PJ, Cochrane GM. Home nebulized therapy for patients with COPD: patient compliance with treatment and its relation to quality of life. Chest 1997;112(5):1278-82. http://dx.doi.org/10.1378/chest.112.5.1278

170. Esteban C, Moraza J, Quintana JM, Aburto M, Capelastegui A. Use of medication and quality of life among patients with COPD. Respir Med 2006;100(3):487-95. http://dx.doi.org/10.1016/j.rmed.2005.06.005

171. Osman LM, Ayres JG, Garden C, Reglitz K, Lyon J, Douglas JG. Home warmth and health status of COPD patients. Eur J Public Health 2008;18(4):399-405. http://dx.doi.org/10.1093/eurpub-2Fckn015

172. Iversen L, Hannaford PC, Price DB, Godden DJ. Is living in a rural area good for your respiratory health? Results from a cross-sectional study in Scotland. Chest 2005;128(4):2059-67. http://dx.doi.org/10.1378/chest.128.4.2059

173. Hesselink AE, Penninx BW, Schlosser BW, et al. The role of coping resourses and coping style in quality of life of patients with asthma or COPD. Qual Life Res 2004;13(2):509-18. http://dx.doi.org/10.1378/chest.128.4.2059

174. McCathie HC, Spence SH, Tate RL. Adjustment to chronic obstructive pulmonary disease: the importance of psychological factors. Eur Respir J 2002;19(1):47-53. http://dx.doi.org/10.1183/09031936.02.00240702

175. Scharloo M, Kaptein AA, Schlösser M, et al. Illness perceptions and quality of life in patients with chronic obstructive pulmonary disease. J Asthma 2007;44(7):575-81. http://dx.doi.org/10.1080/02770900701537438

176. Herbert R, Gregor F. Quality of life and coping strategies of clients with COPD. Rehabil Nurs 1997;22(4):182-7.

177. Holm KE, Bowler RP, Make BJ, Wamboldt FS. Family relationship quality is associated with psychological distress, dyspnea, and quality of life in COPD. COPD 2009;6(5):359-68. http://dx.doi.org/10.1080/15412550903143919

178. Ware JH, Dockery DW, Louis TA, Xu XP, Ferris BG Jr, Speizer FE. Longitudinal and cross-sectional estimates of pulmonary function decline in never-smoking adults. Am J Epidemiol 1990;132(4):685-700.

179. Han MK, Postma D, Mannino DM, et al. Gender and Chronic obstructive pulmonary disease: why it matters. Am J Respir Crit Care Med 2007;176(12):117984. http://dx.doi.org/10.1164/rccm.200704-553CC

180. Chavannes NH, Huibers MJ, Schermer TR, et al. Associations of depressive symptoms with gender, body mass index and dyspnea in primary care COPD patients. Fam Pract 2005;22(6):604-07. http://dx.doi.org/10.1093/fampra/cmi056

181. Sin DD, Jones RL, Man SF. Obesity is a risk factor for dyspnea but not for airflow obstruction. Arch Intern Med 2002;162(13):1477-81. http://dx.doi.org/ 10.1001/archinte.162.13.1477

182. Heyworth IT, Hazell ML, Linehan MF, Frank TL. How do common chronic conditions affect health-related quality of life? Br J Gen Pract 2009;59(568):e353-8. http://dx.doi.org/10.3399/bjgp09X453990

183. Jones PW, Harding G, Berry P, Wiklund I, Chen WH, Kline Leidy N. Development and first validation of the COPD assessment test. Eur Respir J 2009;34(3):648-54.

\section{Available online at http://www.thepcrj.org}

